\title{
Induction of defence gene expression by oligogalacturonic acid requires in- creases in both cytosolic calcium and hydrogen peroxide in Arabidopsis thaliana
}

\author{
Xiang Yang $\mathrm{HU}^{1}$, Steven $\mathrm{J}_{\mathrm{NEILL}}{ }^{2}$, Wei Ming $\mathrm{CAI}^{1, *}$, Zhang Cheng TANG ${ }^{1}$ \\ ${ }^{1}$ Institute of Plant Physiology and Ecology, Shanghai Institutes for Biological Sciences, Chinese Academy of Sciences, \\ Shanghai 200032, China. \\ ${ }^{2}$ Centre for Research in Plant Science, University of the West of England, Bristol, Coldharbour Lane, Bristol BS16 1QY, UK.
}

\begin{abstract}
Responses to oligogalacturonic acid (OGA) were determined in transgenic Arabidopsis thaliana seedlings expressing the calcium reporter protein aequorin. OGA stimulated a rapid, substantial and transient increase in the concentration of cytosolic calcium $\left(\left[\mathrm{Ca}^{2+}\right]_{\text {cyt }}\right)$ that peaked after $c a .15 \mathrm{~s}$. This increase was dose-dependent, saturating at $c a$. $50 \mu \mathrm{g}$ Gal equiv/ml of OGA. OGA also stimulated a rapid generation of $\mathrm{H}_{2} \mathrm{O}_{2}$. A small, rapid increase in $\mathrm{H}_{2} \mathrm{O}_{2}$ content was followed by a much larger oxidative burst, with $\mathrm{H}_{2} \mathrm{O}_{2}$ content peaking after $c a$. 60 min and declining thereafter. Induction of the oxidative burst by OGA was also dose-dependent, with a maximum response again being achieved at $c a$. $50 \mu \mathrm{g}$ Gal equiv/mL. Inhibitors of calcium fluxes inhibited both increases in $\left[\mathrm{Ca}^{2+}\right]_{\text {cyt }}$ and $\left[\mathrm{H}_{2} \mathrm{O}_{2}\right]$, whereas inhibitors of NADPH oxidase blocked only the oxidative burst. OGA increased strongly the expression of the defence-related genes $C H S$, $G S T, P A L$ and $P R-1$. This induction was suppressed by inhibitors of calcium flux or NADPH oxidase, indicating that increases in both cytosolic calcium and $\mathrm{H}_{2} \mathrm{O}_{2}$ are required for OGA-induced gene expression.
\end{abstract}

Keywords: Arabidopsis thaliana, cytosolic calcium, defence gene expression, hydrogen peroxide, OGA.

\section{INTRODUCTION}

Plants activate a series of defence mechanisms following challenges by potential pathogens. One of the earliest characterised events is the oxidative burst, during which reactive oxygen species such as $\mathrm{H}_{2} \mathrm{O}_{2}$ and $\mathrm{O}_{2}{ }^{-}$are rapidly generated $[1,2] \cdot \mathrm{H}_{2} \mathrm{O}_{2}$ production is a key response, as it may orchestrate several processes including cell wall rigidification, transcription of defence-related genes and hypersensitive (programmed) cell death[3-6]. The oxidative burst can also be induced by microbial elicitors such as harpin, fungal peptides and oligogalacturonic acid [OGA, $\left.\left(\mathrm{C}_{6} \mathrm{H}_{11} \mathrm{O}_{10}\right)_{\mathrm{n}}\right][1,7]$. OGA, a well-studied elicitor, is derived from plant cell walls. It induces defence responses including the oxidative burst in various species[7-10], as well as stomatal closure via the stimulation of $\mathrm{H}_{2} \mathrm{O}_{2}$ synthesis[11].

*Correspondence: Wei Ming CAI

Tel: +86-21-64042090-3303, E-mail: wmcai@iris.sipp.ac.cn

Abbreviations: aeq, aequorin gene; $\left[\mathrm{Ca}^{2+}\right]_{\text {cyt }}$, the concentration of cytosolic free calcium ion; CHS, chalcone synthase; DPI, diphenyleneiodonium; Gal equiv, galacturonic acid equivalents; GST, glutathione S-transferase; $\left[\mathrm{H}_{2} \mathrm{O}_{2}\right]$, the concentration of hydrogen peroxide; MS, Murashige and Skoog; OGA, oligogalacturonic acid; PAL, phenylalanine ammonialyase; PR-1, pathogen related protein 1 .
Calcium is a ubiquitous second messenger and changes in cytosolic calcium concentration $\left(\left[\mathrm{Ca}^{2+}\right]_{\text {cyt }}\right)$ are known to mediate many signalling processes in higher plants[1214]. Much evidence has accumulated that increases in $\left[\mathrm{Ca}^{2+}\right]_{\text {cyt }}$ are key to subsequent signalling during plant responses to challenges from pathogens and elicitors[15]. Expression of the aequorin gene from Aequorea aequorea in the cytoplasm of plant cells provides a means for accurate, non-invasive quantification of changes in $\left[\mathrm{Ca}^{2+}\right]_{\text {cyt }}[16]$. When reconstituted with coelenterazine, aequorin acts as a bioluminescent indicator of $\left[\mathrm{Ca}^{2+}\right]_{\text {cyt }}$. Because of the pioneering work of Knight et al[16], aequorin technology has been widely applied in plants to report changes in $\left[\mathrm{Ca}^{2+}\right]_{\text {cyt }}$ in response to abiotic stimuli.

In this paper, the relationship between $\left[\mathrm{Ca}^{2+}\right]_{\text {cyt }}$, the oxidative burst and defence gene expression following challenges with OGA was investigated in Arabidopsis thaliana. Changes in $\left[\mathrm{Ca}^{2+}\right]_{\text {cyt }}$ were monitored in transgenic Arabidopsis seedlings expressing the calcium reporter protein aequorin[16] and inhibitors of calcium fluxes and the oxidative burst were used to manipulate various responses. Our results indicate that increases in cytosolic calcium and $\mathrm{H}_{2} \mathrm{O}_{2}$ are both required for OGA-induced defence gene transcription and expression. 


\section{MATERIALS AND METHODS}

\section{Arabidopsis transformation and Southern analysis}

Arabidopsis thaliana plants (ecotype Landsberg erecta) were grown in pots containing a 1:1 mixture of sand and field soil in a greenhouse under a $16 \mathrm{~h}$ light $/ 8 \mathrm{~h}$ dark cycle at $25^{\circ} \mathrm{C}$. The plasmid pMAQ 2.4[16, 17] was obtained from Dr Heather Knight (University of Oxford, Oxford, UK). pMAQ 2.4 contains the aequorin coding sequence under the control of the CaMV $35 \mathrm{~S}$ promoter and OCS terminator sequences. The plasmid was mobilized to Agrobacterium tumefaciens strain LBA4404 by electroporation (Bio-Rad, Hercules, CA, USA)[18]. Arabidopsis plants (5 W old) were transformed with A. tumefaciens containing pMAQ2.4 via vacuum infiltration and grown in a greenhouse for the collection of seeds as described by Andrew Bent (http://www.Arabidopsis.org). These seeds were then screened on $0.8 \%$ (w/v) agar-solidified Murashige and Skoog (MS) medium supplemented with $50 \mu \mathrm{g} / \mathrm{ml}$ kanamycin, under a $16 \mathrm{~h}$ photoperiod[17]. Seedlings that grew normally on kanamycin for $3 \mathrm{~W}$ were selected as experimental material. Transformation was confirmed by Southern analysis. Genomic DNA from non-transformed and transformed seedlings was digested with different restriction enzymes, fractionated by agarose electrophoresis, blotted onto nylon membrane and hybridized with a dig-labelled aequorin gene probe. The aequorin $(a e q)$ gene probe was labeled and hybridization detected using a Dig DNA labeling and detection kit (CAT NO. 1093657, Roche Diagnostics GmbH, Mannheim, Germany) according to the manufacturer's instructions.

\section{Chemicals and elicitor}

Diphenyleneiodonium (DPI), EGTA, $\mathrm{LaCl}_{3}$, pyridine, quinacrine, imidazole and Ruthenium Red were obtained from Sigma Chemical Co. (USA). They were made up in DMSO as stock solutions. An equivalent amount of DMSO solvent was used as control treatments. Inhibitors were used at concentrations of the same order of magnitude as those reported in Tang and Smith[19] and Orozaco-Cardenas et al[5]. OGA was purified from acid hydrolysate of citrus pectin (Sigma Chemical Co, USA) as described by Nothnagel et al [20] and Legendre et al[7]. It was subsequently dialyzed against distilled water using dialysis tubing with a cut-off of approximately $500 \mathrm{D}$. The prepared OGA was adjusted to a final concentration of $1 \mathrm{mg} / \mathrm{ml}$ of galacturonic acid equivalents (Gal equiv) with distilled water, as determined by the method of Blumenkrantz and AsboeHansen[21]. In inhibitor experiments, seedlings were pre-treated with different inhibitors for $30 \mathrm{~min}$, followed by OGA treatment and then harvested at the indicated times for $\mathrm{H}_{2} \mathrm{O}_{2}$ and $\left[\mathrm{Ca}^{2+}\right]_{\text {cyt }}$ assay.

\section{Measurement of $\mathrm{H}_{2} \mathrm{O}_{2}$}

Seedlings were incubated in Tris- $\mathrm{HCl}$ buffer $(10 \mathrm{mM}, \mathrm{pH}$ 6.0) with OGA at various concentrations, or pre-treated for $30 \mathrm{~min}$ in Tris-HCl buffer containing pharmacological agents at various concentrations, and then OGA was added to give a final concentration of $40 \mu \mathrm{g}$ Gal equiv/ml. At various times seedlings were harvested by flash-freezing in liquid nitrogen and stored at $-70^{\circ} \mathrm{C}$ until subsequent extraction. Frozen leaves $(0.2 \mathrm{~g})$ were ground to powder under liquid nitrogen and homogenized with $1 \mathrm{ml}$ of $0.2 \mathrm{M} \mathrm{HClO}_{4}$ at $4^{\circ} \mathrm{C}$. The extract was held on ice for $5 \mathrm{~min}$ and then centrifuged at $10,000 \mathrm{~g}$ for $10 \mathrm{~min}$ at $4^{\circ} \mathrm{C}$. The supernatant was collected and either processed immediately or quick-frozen at $-70^{\circ} \mathrm{C}$ until further analysis.
The concentration of $\mathrm{H}_{2} \mathrm{O}_{2}$ was measured as described by Chen et al [22].

\section{Measurement of $\left[\mathrm{Ca}^{2+}\right]_{\mathrm{cyt}}$}

Changes in $\left[\mathrm{Ca}^{2+}\right]_{\text {cyt }}$ were measured non-invasively by luminometry of intact seedlings of transgenic Arabidopsis expressing aequorin. Reconstitution of aequorin was performed in vivo essentially as described in Knight et al[17] by floating seedlings on water containing $2.5 \mu \mathrm{M}$ coelenterazine in the dark overnight at $21^{\circ} \mathrm{C}$. Experiments were performed by putting a single seedling in a plastic luminometer cuvette containing $0.2 \mathrm{ml}$ Tris-HCl buffer $(10 \mathrm{mM}, \mathrm{pH} 6.0)$, and then placing the cuvette in a luminometer (FG-200, Shanghai, China). After injecting with the appropriate volume of OGA stock solution $(1 \mathrm{mg} / \mathrm{ml})$, luminescence counts were recorded immediately and calibrated against $\mathrm{Ca}^{2+}$ concentrations as described by Blume et al[23].

\section{Northern-blot analysis}

Total RNA was extracted and subjected to Northern analysis as described in Desikan et al[24] and Orozaco-Cardenas et al[5]. Total RNA $(10 \mu \mathrm{g})$ extracted from seedlings was fractionated by electrophoresis on $1.4 \%$ agarose gels with formaldehyde and blotted onto nitrocellulose membranes. Prehybridization and hybridization were carried out as recommended in the Dig DNA labeling and detection kit (Roche Diagnostics GmbH, Mannheim, Germany). The probes encoding chalcone synthase (CHS, No. 177N23T7), glutathione Stransferase (GST, No. 103G1T7), phenylalanine ammonia-lyase $(P A L$, No. 82B7T7) and actin $(A C T$, No. 172E20T7) were all obtained from the Arabidopsis Biological Resource Center (ABRC; Columbus, OH 43210 USA). The probe for pathogen related protein 1 $(P R-1)$ was obtained from Professor W. Broekaert in Belgium. ACT probe was used as the loading control. Hybridisation was detected as per the manufacturer's recommendations. For inhibitor experiments, seedlings were incubated in liquid MS medium for $6 \mathrm{~h}$ with shaking $(50 \mathrm{rpm})$ in the growth cabinet, with or without pre-treatment of inhibitors prior to RNA extraction.

\section{SDS-PAGE and Western-blot analysis}

Arabidopsis seedlings ( $2 \mathrm{~g}$ wet weight) were ground in a mortar and pestle before adding $2 \mathrm{ml}$ of extraction buffer ( $125 \mathrm{mM}$ Tris-Cl, $7.75 \%[\mathrm{w} / \mathrm{v}]$ SDS, $10 \%[\mathrm{v} / \mathrm{v}]$ mercaptoethanol, $\mathrm{pH} 7.0)$ and grinding further. The mixture was transferred to a centrifuge tube, raised to room temperature, and centrifuged in a swing-out rotor at $3,500 \mathrm{~g}$ for $10 \mathrm{~min}$. The supernatant containing $30 \mu \mathrm{g}$ total protein was mixed with $6 \times(\mathrm{v} / \mathrm{v})$ sample buffer $(0.1 \mathrm{M}$ Tris-Cl, $12 \%$ [w/v] SDS, $9 \%$ [v/v] glycerol, $60 \%$ [v/v] mercaptoethanol, $\mathrm{pH} 6.8)$ and was separated by SDS-PAGE. After electrophoresis, the separated proteins were transferred to a Hybond-C Extra nitrocellulose membrane (Amersham Pharmacia Biotech, Sydney) using a Multiphor II semi-dry blotting apparatus (Amersham Pharmacia Biotech, Sydney) according to the manufacturer's instructions. Hybrids were detected using the BM Chemiluminescence Blotting Substrate POD system (Roche). Rabbit antibodies against Arabidopsis thaliana PR-1(1:1000), CHS(1: 1000), GST(1:1500) and PAL(1:500) were used.

\section{RESULTS}

\section{Arabidopsis transformation}

F1 seeds from aequorin-transformed plants were plated 
A

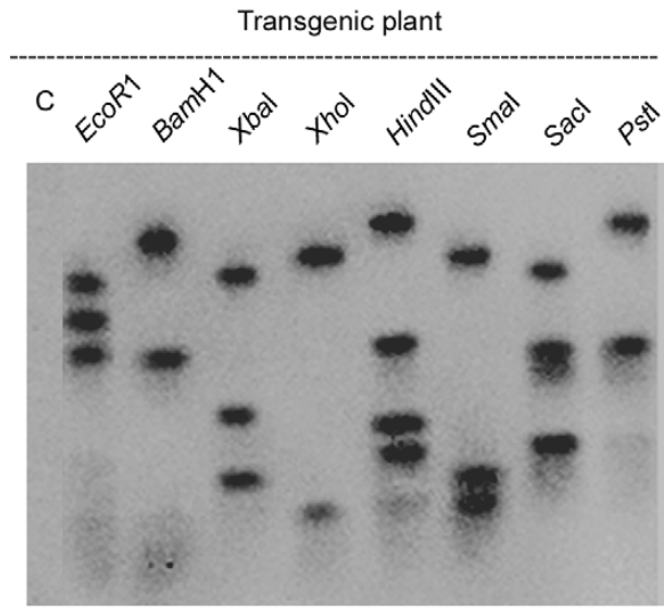

B

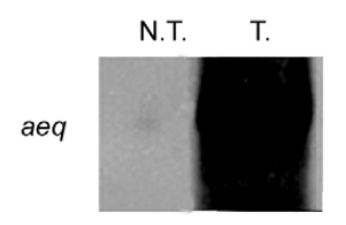

Fig 1. Transformation of Arabidopsis with aequorin. (A) Genomic DNA was extracted from non-transformed (C) and transformed seedlings and $30 \mu \mathrm{g}$ genomic DNA were digested by various restriction enzymes and fractionated by agarose electrophoresis. The gel was then blotted onto nylon membrane and the membrane hybridized with a dig-labelled aequorin gene probe. (B) Total RNA $(20 \mu \mathrm{g})$ from non-transformed (N.T.) and transformed (T.) seedlings was subjected to Northern analysis using a dig-labelled aequorin gene probe. aeq, aequorin transcript.

on MS + kanamycin agar medium and after 3 weeks kanamycin-tolerant seedlings were selected. Southern analysis indicated that the plants were sucessfully transformed, and contained 3-6 copies of the aequorin gene (Fig 1A). Northern blot analysis demonstrated that the inserted aequorin gene was expressed normally (Fig 1B). To confirm the presence of the active aequorin protein, transgenic seedlings were exposed to $100 \mathrm{mM}$ calcium and aequorin luminescence was determined as described in Materials and Methods. A sharp and transient increase in luminescence induced by extracellular calcium was observed only on the transformed seedlings (Fig 2).

\section{Increases in cytosolic calcium induced by OGA are modulated by inhibitors of calcium fluxes but not by inhibitors of the oxidative burst}

OGA at $40 \mu \mathrm{g}$ Gal equiv/ml induced a rapid and substantial transient increase in $\left[\mathrm{Ca}^{2+}\right]_{\mathrm{cyt}}$ that peaked within ca. $15 \mathrm{sec}$ (Fig 3A). This response to OGA was dosedependent: an OGA concentration as low as $10 \mu \mathrm{g}$ Gal equiv/ $\mathrm{ml}$ induced a detectable increase in cytosolic calcium, which was saturated at OGA concentrations above $50 \mu \mathrm{g} \mathrm{Gal}$

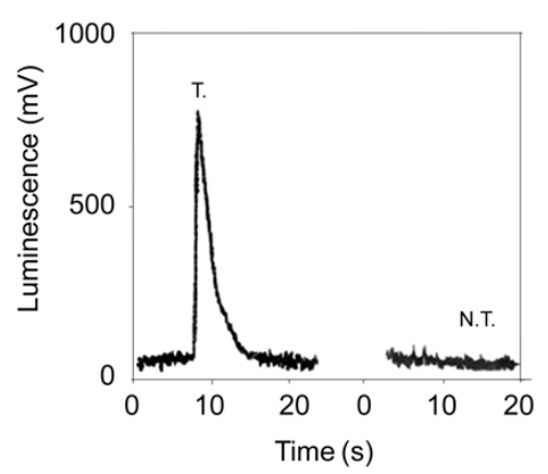

Fig 2. Extracellular calcium triggers a transient increase in luminescence only in Arabidopsis seedlings expressing recombinant aequorin protein. Seedlings transformed with aequorin (T.) or non-transformed (N.T.) were exposed to $100 \mathrm{mM} \mathrm{Ca}^{2+}$ and luminescence determined using a luminometer.

equiv/ml (Fig 3B). Pre-treatment with the calcium chelator EGTA or the calcium channel blockers $\mathrm{LaCl}_{3}$ or Ruthenium Red (Fig 3C) suppressed substantially the OGA-induced increase in $\left[\mathrm{Ca}^{2+}\right]_{\text {cyt. }}$. However, pre-treatment with the NADPH oxidase inhibitors DPI and pyridine (Fig 3C) had no effect on the transient increase in $\left[\mathrm{Ca}^{2+}\right]_{\text {cyt }}$ caused by OGA treatment.

\section{OGA-induced oxidative burst is blocked by inhibitors of NADPH oxidase}

OGA-induced $\mathrm{H}_{2} \mathrm{O}_{2}$ accumulation occurred in a biphasic fashion (Fig 4A). The initial increase by $40 \mu \mathrm{g} \mathrm{Gal}$ equiv/ml OGA peaked at $c a .5 \mathrm{~min}$. The $\mathrm{H}_{2} \mathrm{O}_{2}$ content then declined again to control values. A second, much larger increase in $\mathrm{H}_{2} \mathrm{O}_{2}$ content, which peaked at $c a$. 60 min and declined thereafter, was observed (Fig 4A). Similar to the effect on $\left[\mathrm{Ca}^{2+}\right]_{\text {cyt }}$, the response of $\mathrm{H}_{2} \mathrm{O}_{2}$ production to OGA was also dose-dependent and saturated at $50 \mu \mathrm{g} \mathrm{Gal}$ equiv/ml (Fig 4B). OGA-induced $\mathrm{H}_{2} \mathrm{O}_{2}$ production was effectively eliminated by pre-treatment with the NADPH oxidase inhibitors quinacrine, DPI, pyridine and imidazole (Fig 4C). Pre-treatment with the calcium channel blockers $\mathrm{LaCl}_{3}$, Ruthenium Red and, to a much lesser extent, with the calcium chelator EGTA, also inhibited the OGA-induced oxidative burst (Fig 4C).

\section{Induction of defence gene transcription by OGA}

OGA treatment for $6 \mathrm{~h}$ at $40 \mu \mathrm{g}$ Gal equiv/ml increased the transcription of $C H S, P R-1, G S T$ and $P A L$, compared to the control. Treatment with the NADPH oxidase inhibitors DPI and pyridine inhibited the OGA-induced increases in the transcription of these genes. Treatment with the calcium flux inhibitors EGTA, $\mathrm{LaCl}_{3}$ and Ruthenium Red also reduced substantially the induction of gene expression 
A

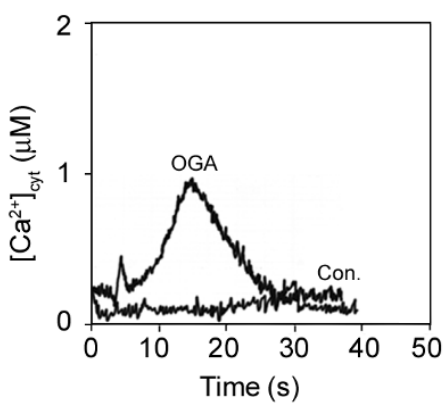

B

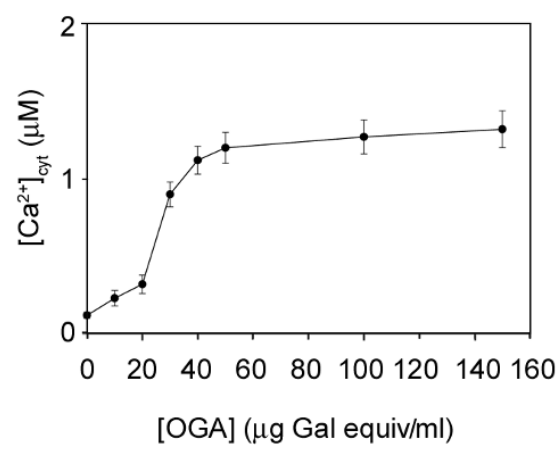

C

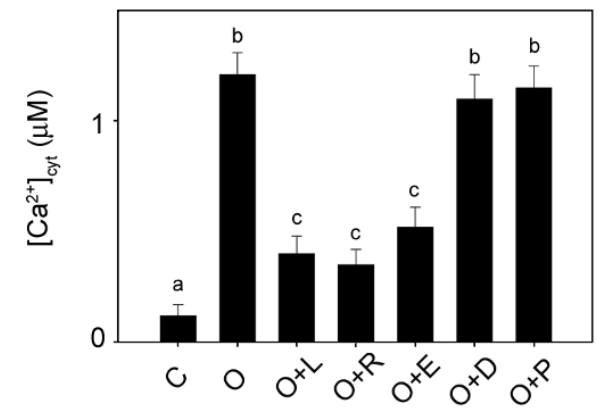

Fig 3. Effects of inhibitors of $\mathrm{Ca}^{2+}$ flux and NADPH oxidase on OGA-induced transient increases in $\left[\mathrm{Ca}^{2+}\right]_{\text {cyt }}$ in Arabidopsis seedlings. (A) Increase in $\left[\mathrm{Ca}^{2+}\right]_{\text {cyt }}$ induced by OGA at $40 \mu \mathrm{g} \mathrm{Gal}$ equiv $/ \mathrm{ml}$. OGA, oligogalacturonic acid treatment; Con, control. Experiments were repeated at least six times. (B) Dose-response for maximum increase in $\left[\mathrm{Ca}^{2+}\right]_{\text {cyt }}$ against OGA concentration. (C) The effects of calcium flux inhibitors (L, $10 \mu \mathrm{M} \mathrm{LaCl}_{3} ; \mathrm{R}, 100 \mu \mathrm{M}$ Ruthenium Red; E, 1mM EGTA) and NADPH oxidase inhibitors (D, $10 \mu \mathrm{M}$ DPI; P, $10 \mathrm{mM}$ pyridine $)$ on the OGA- $(\mathrm{O}, 40 \mu \mathrm{g}$ Gal equiv/ml) induced increase in $\left[\mathrm{Ca}^{2+}\right]_{\mathrm{cyt}}$. C, Control. Seedlings were pre-incubated for 30 min prior to OGA challenge. Data in B and C represents the means \pm SE from six experiments and was analysed by one-way ANOVA followed by Tukey's test. Different symbols indicate significant differences between treatments $(\mathrm{p}<0.05)$.

by OGA compared to OGA treatment alone (Fig 5).

\section{Accumulation of defence gene products induced by OGA}

Similar to its effects on gene transcription, OGA treatment for $36 \mathrm{~h}$ at $40 \mu \mathrm{g}$ Gal equiv/ml also induced the
A

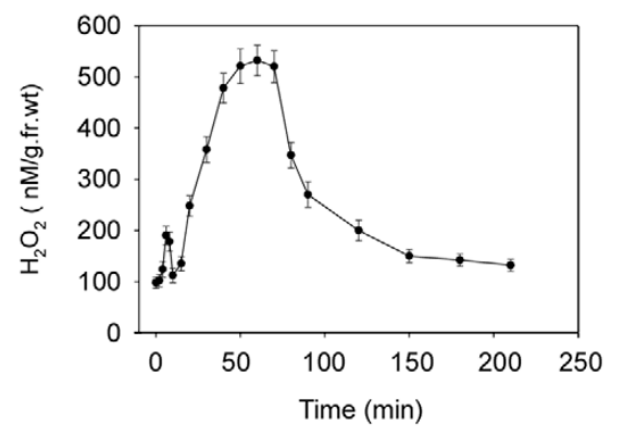

B

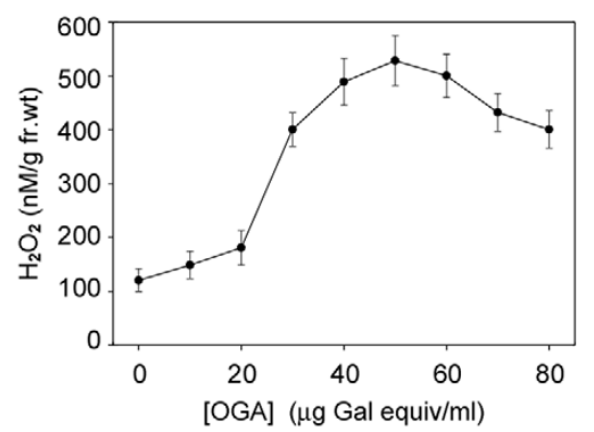

C

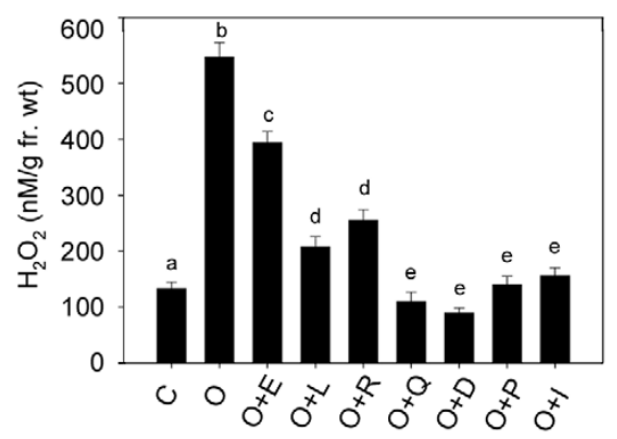

Fig 4. Effects of inhibitors of calcium flux and NADPH oxidase on the OGA-induced oxidative burst in Arabidopsis seedlings (A) Timecourse of $\mathrm{H}_{2} \mathrm{O}_{2}$ accumulation induced by $40 \mu \mathrm{g}$ Gal equiv/ml OGA. (B) Dose-response (60 min). (C) The effects of calcium flux inhibitors (L, $10 \mu \mathrm{M} \mathrm{LaCl}_{3}$; R, $100 \mu \mathrm{M}$ Ruthenium Red; E, 1mM EGTA) and NADPH oxidase inhibitors (I, $10 \mathrm{mM}$ imidazole; Q, $100 \mu \mathrm{M}$ quinacrine; D, $10 \mu \mathrm{M}$ DPI; P, $10 \mathrm{mM}$ pyridine) on OGA- (O, $40 \mu \mathrm{g}$ $\mathrm{Gal}$ equiv/ml) induced increases in $\mathrm{H}_{2} \mathrm{O}_{2}$ accumulation (60 min). C, Control. Seedlings were pre-incubated for $30 \mathrm{~min}$ prior to OGA challenge. Data represents the means $\pm \mathrm{SE}$ from six experiments and was analysed by one-way ANOVA followed by Tukey's test. Different symbols indicate significant differences between treatments $(\mathrm{p}<0.05)$.

accumulation of PR-1, CHS, PAL and GST proteins. DPI, pyridine, EGTA, $\mathrm{LaCl}_{3}$ and Ruthenium Red pretreatments for 30 min inhibited the OGA-induced accumulation of PR-1, CHS, PAL and GST (Fig 6).

\section{DISCUSSION}


A
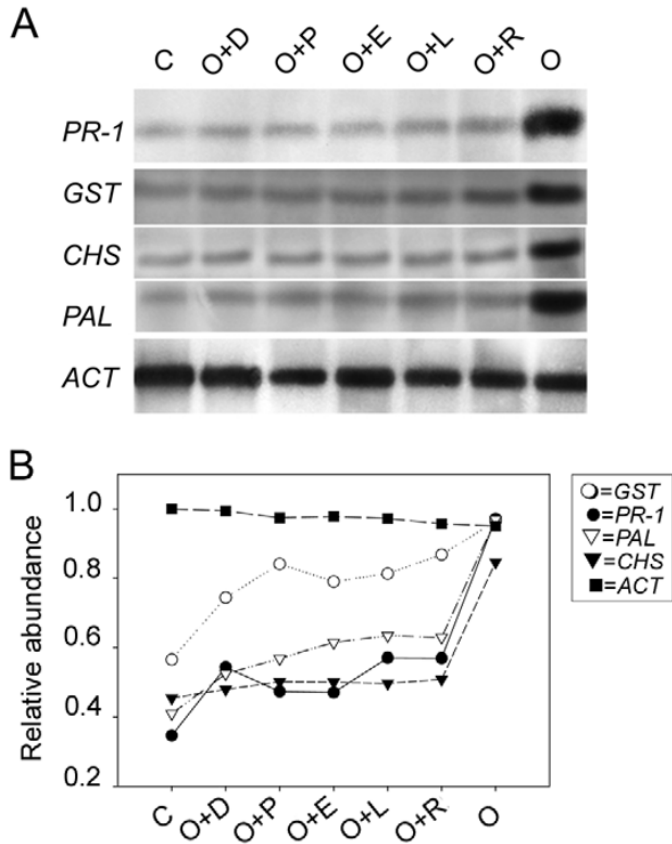

Fig 5. Suppression of OGA-induced defence gene transcription of $P R-1, C H S, G S T$ and $P A L$ by various inhibitors. Seedlings were pretreated in buffer or various inhibitors $\left(\mathrm{L}, 10 \mu \mathrm{M} \mathrm{LaCl}_{3} ; \mathrm{R}, 100 \mu \mathrm{M}\right.$ Ruthenium Red; E, $1 \mu \mathrm{M}$ EGTA; D, $10 \mu \mathrm{M}$ DPI; P, $10 \mathrm{mM}$ pyridine) for $30 \mathrm{~min}$ prior to exposure to OGA ( $40 \mu \mathrm{g}$ Gal equiv/ml). (A), RNA was then extracted after $6 \mathrm{~h}$ of OGA treatment ( $40 \mu \mathrm{g}$ Gal equiv/ml) and the resulting blots hybridized to dig-labelled PR-1, CHS, GST or $P A L$ gene probes. Blots were subsequently stripped and re-probed with an actin $(A C T)$ probe to confirm equal RNA loading. (B) shows the relative abundance of gene transcription from (A). The maximum RNA amount was taken as 1.0.

Plants transformed with a cDNA encoding the $\mathrm{Ca}^{2+}-$ sensitive luminescent protein aequorin provide a simple, non-invasive means of measuring $\left[\mathrm{Ca}^{2+}\right]_{\text {cyt }}$ in whole plants. Many new signals initiating rapid changes in $\left[\mathrm{Ca}^{2+}\right]_{\text {cyt }}$ have subsequently been detected with this technology, including the mechanical signals of touch and wind, salt/drought, heat shock, and osmotic stress. Such technology has also been used to study pathogen- or pathogen-derived elicitor -induced calcium signalling, but the effects of endogenous elicitors (such as OGA, derived from the plant cell wall) have not been analysed. Thus in order to determine the effects of the endogenous elicitor OGA on calcium fluxes and the oxidative burst in Arabidopsis, transgenic seedlings expressing the calcium reporter protein aequorin were generated. Southern and Northern analyses (Fig 1A, B), coupled to the induction of luminescence by extracellular calcium (Fig 2), demonstrated that these seedlings were suitable for such studies.

OGA induces the oxidative burst in tobacco, tomato and Commelina communis[7, 11, 25]. In the present study,

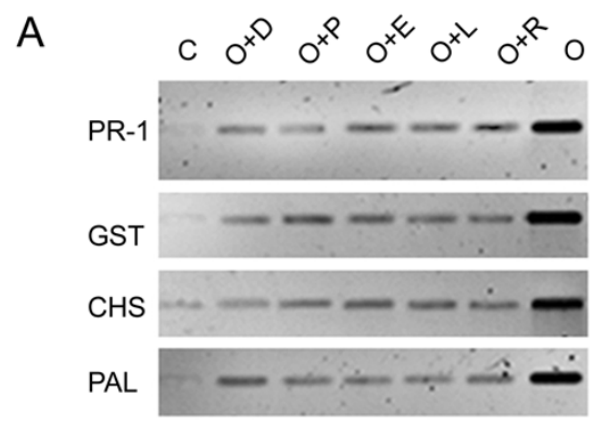

B

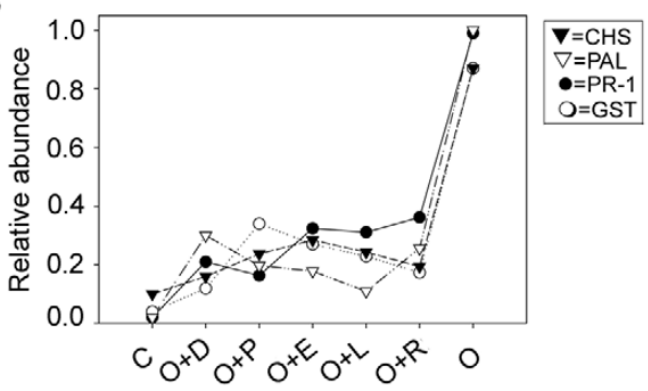

Fig 6. Accumulation of defence gene products induced by OGA. (A) Total protein was extracted after $36 \mathrm{~h}$ of OGA treatment $(40 \mu \mathrm{g}$ Gal equiv/ml) and Western blotting was performed with anti-PR-1, antiCHS, anti-GST, and anti-PAL antibodies. C, control; O, OGA treatment; $\mathrm{O}+\mathrm{L}$, pretreated with $\mathrm{LaCl}_{3}$ for 30 min following with OGA; O+R, pretreated with RR for 30 min following with OGA; $\mathrm{O}+\mathrm{E}$, pretreated with EGTA following with OGA; O+D, pretreated with DPI for 30 min following with OGA; O+P, pretreated with pyridine following with OGA. (B) shows the relative abundance of protein accumulation from $(\mathbf{A})$. The maximum protein amount was taken as 1.0 .

OGA not only strongly induced $\mathrm{H}_{2} \mathrm{O}_{2}$ production, it also induced a substantial increase in $\left[\mathrm{Ca}^{2+}\right]_{\text {cyt. }}$. Furthermore, OGA-stimulated increases in $\left[\mathrm{Ca}^{2+}\right]_{\text {cyt }}$ and $\mathrm{H}_{2} \mathrm{O}_{2}$ production were rapid and saturable, suggesting the existence of a receptor mediating OGA effects (Fig 3A, B; Fig 4A, B). There is considerable evidence that the elicitor- and pathogen-induced oxidative bursts in Arabidopsis are mediated by Atrboh proteins, homologues of the gp91 sub-unit of mammalian NADPH oxidase[26]. Several Atrboh genes have been cloned from Arabidopsis [27-29]. Elicitor- or pathogen-induced oxidative bursts are inhibited by known inhibitors of NADPH oxidase [4, 24] and $\mathrm{H}_{2} \mathrm{O}_{2}$ accumulation is also much reduced in Atrboh knock-out mutants [26], although the possibility that alternative $\mathrm{H}_{2} \mathrm{O}_{2}$-generating systems operate in Arabidopsis must be borne in mind[30]. Nevertheless, in the present study, known inhibitors of plasma membrane NADPH oxidase (DPI or pyridine) did eliminate the OGA-induced oxidative burst in Arabidopsis seedlings (Fig 4C), suggesting that plasma membrane NADPH oxidase was responsible for the OGA- 
induced oxidative burst. In addition, the OGA-stimulated rapid and substantial increase of cytsolic calcium was inhibited by EGTA (a calcium chelator), $\mathrm{LaCl}_{3}$ (a plasma membrane calcium channel blocker) and Ruthenium Red (an intracellular membrane calcium channel blocker), but not by DPI or pyridine (inhibitors of the oxidative burst) (Fig 3C). These data indicate that the oxidative burst is not required for the increases in $\left[\mathrm{Ca}^{2+}\right]_{\text {cyt. }}$ Since both $\mathrm{Ru}-$ thenium Red and $\mathrm{LaCl}_{3}$ inhibited OGA-induced increase in cytosolic calcium, it is likely that calcium fluxes from both extracellular and intracellular pools are required for calcium increases. EGTA, which chelates extracellular calcium ions, also blocked OGA-induced increased $\left[\mathrm{Ca}^{2+}\right]_{\mathrm{cyt}}$ and $\mathrm{H}_{2} \mathrm{O}_{2}$ production, but the effect was not as substantial as those of $\mathrm{LaCl}_{3}$ or Ruthenium Red. Cessna and Low[10] reported that extracellular calcium was not essential for OGA-stimulated $\left[\mathrm{Ca}^{2+}\right]_{\text {cyt }}$ increases in Nicotiana tabacum suspension cultures. On the other hand, Desikan et al[31] reported that the calcium ionophore ionomycin stimulated, and EGTA inhibited, the oxidative burst in Arabidopsis suspension cultures induced by the bacterial elicitor harpin [32]. It may be that different calcium pools are utilized in different species or in response to different stimuli, a suggestion previously made by Cessna and Low[10]. However, whatever the source of calcium for the increase in $\left[\mathrm{Ca}^{2+}\right]_{\text {cyt }}$ is, this increase in cytosolic calcium is necessary for the subsequent oxidative burst. This is evident from the observation that inhibitors of calcium fluxes reduced both the oxidative burst and calcium increase, whereas the oxidative burst inhibitors completely suppressed $\mathrm{H}_{2} \mathrm{O}_{2}$ accumulation but had no effect on $\left[\mathrm{Ca}^{2+}\right]_{\text {cyt. }}$ Grant et al (2000) also provided evidence that increased $\left[\mathrm{Ca}^{2+}\right]_{\text {cyt }}$ precedes and is required for the oxidative burst in Arabidopsis plants [15]. The downstream processes mediating calcium responses have yet to be clearly resolved, but are likely to involve post-translational modifications of enzymes such as protein kinases and protein phosphatases, and even the NADPH oxidase itself[28].

OGA has previously been reported to induce defence responses in soybean, tomato and tobacco cells[7, 11, 25]. Cytosolic calcium and $\mathrm{H}_{2} \mathrm{O}_{2}$ are both known to modulate defence gene expression following exposure of plant cells to various stresses[6, 14]. The data reported here show that OGA similarly induces defence responses in seedlings of Arabidopsis thaliana, including the transcription of $P R-1$, CHS, GST, PAL genes and accumulation of PR-1, CHS, PAL and GST proteins. Induction of these genes and proteins is inhibited by treatments which reduces the increases in $\left[\mathrm{Ca}^{2+}\right]_{\mathrm{cyt}}$ and the oxidative burst, indicating that both calcium and $\mathrm{H}_{2} \mathrm{O}_{2}$ were required for OGA-activated defence gene expression.

\section{ACKNOWLEDGEMENTS}

This work was supported by the National Natural Science Foundation of China (No. 39870050) and the Chinese Academy of Sciences (Grant No. KSCX2-SW-322). Dr H Knight (University of Oxford, UK) kindly provided the pMAQ 2.4 plasmid. Professor WF Broekaert (Katholieke Universiteit Leuven, Belgium) kindly provided the PR-1 probe. Anti-PR-1, PAL, CHS and GST antibodies were obtained from Professor IE Somssich (Max-Planck Institute, Jena, Germany) and Professor S Kauffmann (Université Louis Pasteur, 67084 Strasbourg cedex, France).

Received, Jun 25, 2003

Revised, Apr 14, 2004

Accepted, Apr 16, 2004

\section{REFERENCES}

1 Lamb C, Dixon RA. The oxidative burst in plant disease resistance. Annu Rev Plant Physiol Plant Mol Biol 1997; 48:251-75.

2 Wojtaszek B. Oxidative burst: an early plant response to pathogen infection. Biochem J 1997; 322:681-92.

3 Levine A, Tenhaken R, Dixon R, Lamb C. $\mathrm{H}_{2} \mathrm{O}_{2}$ from the oxidative burst orchestrates the plant hypersensitive disease resistance response. Cell 1994; 79:583-9.

4 Grant JJ, Loake GJ. Role of reactive oxygen intermediates and cognate redox signaling in disease resistance. Plant Physiol 2000; 124:21-30.

5 Orozco-Cardenas ML, Narvaez-Vasquez J, Ryan CA. Hydrogen peroxide acts as a second messenger for the induction of defense genes in tomato plants in response to wounding, systemin and methyl jasmonate. Plant Cell 2001; 13:179-91.

6 Neill SJ, Desikan R, Clarke A, Hurst RD, Hancock JT. Hydrogen peroxide and nitric oxide as signaling molecules in plants. $\mathrm{J}$ Exp Bot 2002; 53:1237-47.

7 Legendre L, Rueter S, Heinstein PF, Low PS. Characterisation of the oligalacturonide-induced oxidative burst in cultured soybean (Glycine max) cells. Plant Physiol 1993; 102:233-40.

8 Messiaen J, Van Custem P. Defense gene transcription in carrot cells treated with oligogalacturonides. Plant Cell Physiol 1993; 34:1117-23.

9 Chandra S, Low PS. Measurement of $\mathrm{Ca}^{2+}$ fluxes during elicitation of the oxidative burst in aequorin-transformed tobacco cells. J Biol Chem 1997; 272:28274-80.

10 Cessna SG, Low PS. Activation of the oxidative burst in aequorintransformed Nicotiana tabacum cells is mediated by protein kinase- and anion channel-dependent release of $\mathrm{Ca}^{2+}$ from internal stores. Planta 2001; 214:126-34.

11 Lee S, Choi H, Suh S, et al. Oligagalacturonic acid and chitosan reduce stomatal aperture by inducing the evolution of reactive oxygen species from guard cells of tomato and Commelina communis. Plant Physiol 1999; 121:147-52.

12 Trewavas AL, Malho R. $\mathrm{Ca}^{2+}$ signaling in plant cells: the big network! Curr Opin Plant Biol 1998; 1:428-33.

13 Reddy A. Calcium: Silver bullet in signaling. Plant Sciences 2000; 160:381-404.

14 Knight H, Knight MR. Abiotic stress signalling pathways: 
specificity and cross talk. Trends in Plant Sciences 2001; 6:262-7.

15 Grant M, Brown I, Adams S, Knight M, Ainslie A, Mansfield J. The RPM1 plant disease resistance gene facilitates a rapid and sustained increase in cytosolic calcium that is necessary for the oxidative burst and hypersensitive cell death. Plant J 2000; 23: 441-50.

16 Knight MR, Campbell AK, Smith SM, Trewavas AJ. Transgenic plant aequorin reports the effects of touch and cold-shock and elicitors on cytoplasmic calcium. Nature 1991; 352:524-6

17 Knight H, Brandt S, Knight MR. A history of stress alters drought calcium signalling pathways in Arabidopsis. Plant J 1998; 16: 681-7

18 Hood EE, Gelvin SB, Melchers LS, Hoekema A. New Agrobacterium helper plasmids for gene transfer to plants. Transgenic Res 1993; 2:208-18.

19 Tang M, Smith JC. Elicitor induced defense response in Medicago sativa. New Phytologist 2001; 149:401-18.

20 Nothnagel EA, McNeil M, Albersheim P, Dell A. Host pathogen interaction XXII: A galacturonic acid oligosaccharide from plant cell walls elicits phytoalexins. Plant Physiol 1983; 71:916-26.

21 Blumenkrantz N, Asboe-Hansen G. New method for quantitative determination of uronic acids. Anal Biochem 1973; 54:484-9.

22 Chen Z, Silva H, Klessig DF. Active oxygen species in the induction of plant systemic acquired resistance by salicylic acid. Science 1993; 262:1883-6.

23 Blume B, Nurnberger T, Nass N, Scheel D. Receptor-mediated increase in cytoplasmic free calcium required for activation of pathogen defense in parsley. Plant Cell 2000; 12:1425-40.

24 Desikan R, Hancock JT, Coffey MJ, Neill SJ. Generation of active oxygen in elicited cells of Arabidopsis thaliana is mediated by a NADPH oxidase-like enzyme. FEBS Lett 1996; 382:213-7.

25 Doares SH, Syrovets T, Weiler EW, Ryan CA. Oligogalacturo- nides and chitosan activate plant defensive genes through the octadecanoid pathway. Proc Natl Acad Sci USA 1995; 92:4095-8.

26 Torres MA, Dangl JL, Jones JDG. Arabidopsis gp $91^{\text {phox }}$ homologues AtrbohD and AtrbohF are required for accumulation of reactive oxygen intermediates in the plant defense response. Proc Natl Acad Sci USA 2002; 99:517-22.

27 Desikan R, Burnet EC, Hancock JT, Neill SJ. Harpin and hydrogen peroxide induce the expression of a homologue of gp91phox in Arabidopsis thaliana suspension cultures. J Exp Bot 1998; 49:1767-71.

28 Keller T, Damude HG, Werner D, et al. A plant homologue of the neutrophil NADPH oxidase gp $91^{\text {phox }}$ subunit gene encodes a plasma membrane protein with $\mathrm{Ca}^{2+}$ binding motifs. Plant Cell 1998; 10:255-66.

29 Desikan R, Reynolds A, Hancock JT, Neill SJ. Harpin and hydrogen peroxide both initiate programmed cell death but have differential effects on defense gene expression in Arabidopsis suspension cultures. Biochem J 1998; 330:115-20.

30 Bolwell JP. Role of active oxygen species and NO in plant defence responses. Curr Opin Plant Biol 1999; 2:287-94.

31 Desikan R, Neill SJ, Hancock JT. Generation of active oxygen in suspension cultures of Arabidopsis thaliana. Phyton 1997; 37: 65-70.

32 Clarke A. Nitric oxide and hydrogen peroxide-mediated defence responses in Arabidopsis thaliana. $\mathrm{PhD}$ thesis. University of the West of England, Bristol, UK. 2001.

33 Desikan R, A-H-Mackerness S, Hancock JT, Neill SJ. Regulation of the Arabidopsis transcriptome by oxidative stress. Plant Physiol 2001; 127:159-72.

34 Desikan R, Hancock JT, Coffey MJ, Neill SJ. Generation of active oxygen in elicited cells of Arabidopsis thaliana is mediated by a NADPH oxidase-like enzyme. FEBS Lett 1996; 382:213-7. 